\title{
214 球面モータを用いたレーザ追尾式干渉計装置の開発
}

The development of using a spherical surface motor

○准 梅津 健太 (東京電機大学) 正 高辻 利之（産業技術総合研究所）

正鈴木 健生（安川電機）正 矢野 智昭（産業技術総合研究所）

Kenta UMETSU, Tokyo Denki University

Tosiyuki TAKATSUJI, National Institute of Advanced Industrial Science and Technology

Tomoaki YANO, National Institute of Advanced Industrial Science and Technology

Takeo SUZUKI, Yaskawa Electroric Corporation

Coordinate measuring machines (CMM) and robots in industry require accurate and easy calibration over a wide measuring-range. The new calibration instrument (laser tracking interferometer) we produced makes use of a spherical surface motor for laser tracking mechanism. This enabled wide-range measurement for middle size CMM because the movable angle of the spherical surface motor is so wide. In this paper, we refer to the accuracy of the new laser tracking interferometer based on our experiment.

Key words: Laser tracking interferometer, Spherical surface motor

\section{1. 緒言}

産業用ロボットや三次元測定機（以下 CMM）の位置決め精 度の校正には幾何学的なゲージやレーザ干涉計が広く利用さ れている.幾何学的なゲージはその操作性から支持されている 一方で,測定点配置の自由度が低く,高精度な测定が困難であ るといった問題がある。

レーザ干涉計を用いた校正では高精度な測定が期待できる ものの,光軸のアライメントが困難であるためロボット, CMM の使用者自らが校正作業をするには不向きである.

これらの問題に対し高い操作性と高精度な校正が期待でき るレーザ追尾式干涉計装置が開発されている 1).開発されたレ ーザ追尾式干渉計装置は大型の CMM やロボットなど,レーザ 追尾式干渉計装置の配置に自由度がある場合には適用が可能 であるものの, 汎用 CMMにおいては測定領域が小さくなるた め改善の必要性がある.そこで本研究ではレーザ追尾機構に球 面モー夕を採用し，広域の測定領域を高精度に測定すること を目指した.今回,開発した装置の測定精度の評価を行ったた めその結果を報告する.

\section{2. レーザ追尾式干涉計装置}

開発したレーザ追尾式干涉計システムの概略図を図 1 に示 す.このシステムでは測定空間内で自由に移動するレトロリフ レクターをレーザ追尾する.これより測定開始点を基淮に，レ 一ザ追尾式干涉計装置からレトロリフレクタ一までの相対的 な移動量をリアルタイムで計測することができる.

レーザ追尾用の半球ミラーの駆動には二軸方向の回転機構 が要求されるが,これに対し本研究では球面モー夕を採用した

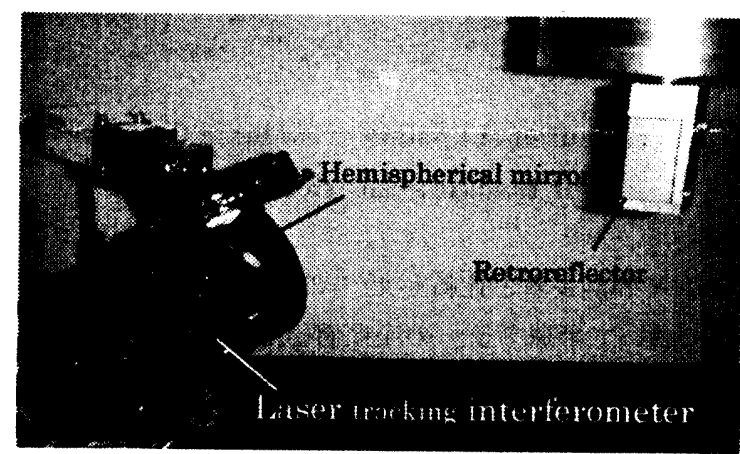

Fig.1 A laser tracking interferometer using a spherical surface motor

球面モータは二台のステッピングモータが入れ子になって おり,内側のモータ可動子が外側の固定子に固定され,外側の 可動子がモータベースに固定されている.各ステッピングモー タの回転軸は一点で交差し,出力軸を任意方向に向けることが できる ${ }^{2}$. 球面モータの動作範囲は外側,内側ともに 90 度であ り,広域にわたりレーザ追尾が可能である。

\section{3. 测定精度評価}

開発したレーザ追尾式干涉計システムの測定精度を評価す るため,測定精度 0.6 $L / 600(L$ : 測定長 [m]) [ $\mu \mathrm{m}$ ]を有する三 次元測定機(Brown\&sharp 社 PMM12106)を用いた.

図 2 に示すとおり CMM の Z 軸に取り付けられたレトロリ フレクターを $\mathrm{CMM}$ の測定空間のうち $120 \times 120 \times 80 \mathrm{~mm}^{3}$ を 用い移動させた.このとき CMM が指示する三次元座標值を基 準值とし,レーザ追尾式干涉計の半球ミラーからレトロリフレ

日本機械学会 [No.03-03]第 3 回機素潤滑設計部門講演会講演論文集 [’03-4-21,22,浦安市] 


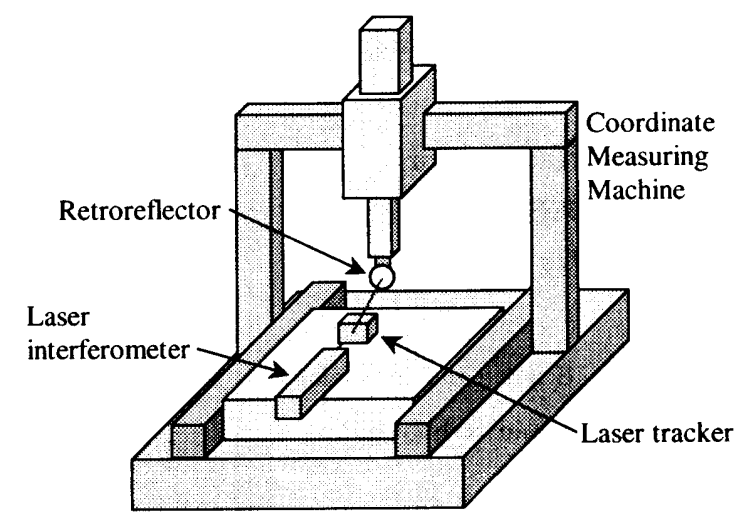

Fig.2 A schematic diagram of experimental instruments

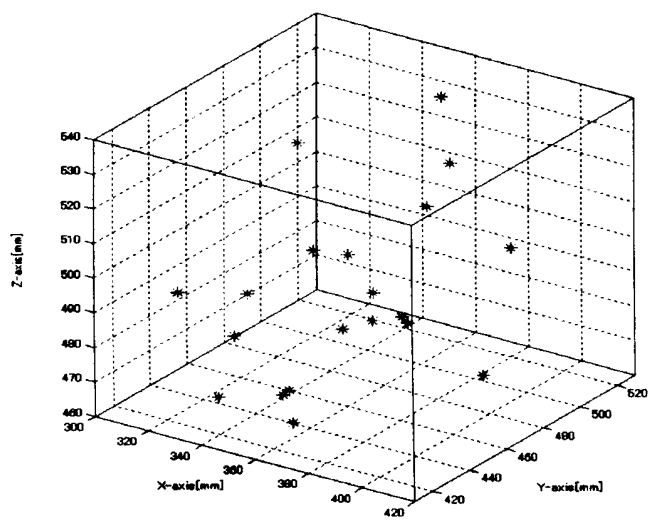

Fig.3 The measurement points to evaluate the new laser tracking interferometer

クターまでの測長值と比較した.このとき CMM の直交座標系 $\mathbf{x}-\mathbf{y}-\mathbf{z}$ において半球ミラーの座標値 $(\mathbf{p}, \mathbf{q}, \mathbf{r})$ と座標( $(\mathbf{p}, \mathbf{q}, \mathbf{r})$ から測 定開始点までの初期長 $l_{0}$ は未知なシステムパラメータである. よって立体的に配した複数の点でのレーザ干涉計の指示值 $\mathrm{d}_{\mathrm{i}}$ より,式(1)の目的関数 R を最小化するよう Gauss-Newton 法 で算出するものとする. 表 1 にはシステムパラメータ算出に 用いた CMM の三次元座標 8 点と算出結果を示す.

$$
R=\sum_{i=1}^{8}\left[\sqrt{\left(x_{i}-p\right)^{2}+\left(y_{i}-q\right)^{2}+\left(z_{i}-r\right)^{2}}-\left(l_{0}+d_{i}\right)\right]^{2}
$$

レーザ追尾式干涉計の精度評価には算出したシステムパラ メータを用い, 式(2)のとおりある座標におけるレーザ追尾式 干涉計の指示值と CMM の指示値を比較する.

このとき測定点はレーザ追尾式干渉計の動作特性が発生し ないよう図 3 に示すとおり, 三次座標 $(300,410,460)$, $(420,530,540)$ を対角とした $120 \times 120 \times 80 \mathrm{~mm}^{3}$ 内をランダム に 20 点選択した.またこれらの测定点はシステムパラメータ 算出に用いた 8 点の三次元座標とも区別される.

$$
e r r_{i}=\sqrt{\left(x_{i}-p\right)^{2}+\left(y_{i}-q\right)^{2}+\left(z_{i}-r\right)^{2}}-\left(l_{0}+d_{i}\right) \quad i=1 . .20
$$

Table1. The selected measurement points to estimate system parameter

\begin{tabular}{c|c|c|c|c}
\hline No. & $\mathrm{x}[\mathrm{mm}]$ & $\mathrm{Y}[\mathrm{mm}]$ & $\mathrm{z}[\mathrm{mm}]$ & $\mathrm{d}_{\mathrm{i}}[\mathrm{mm}]$ \\
\hline 1 & 300 & 410 & 540 & 13.8353 \\
\hline 2 & 300 & 530 & 540 & 45.3766 \\
\hline 3 & 420 & 530 & 540 & -52.3031 \\
\hline 4 & 420 & 410 & 540 & -88.5715 \\
\hline 5 & 300 & 410 & 460 & -18.25397 \\
\hline 6 & 300 & 530 & 460 & 14.633848 \\
\hline 7 & 420 & 530 & 460 & -87.64617 \\
\hline 8 & 420 & 410 & 460 & -126.0052 \\
\hline \multirow{2}{*}{$\begin{array}{c}\text { System } \\
\text { parameter }\end{array}$} & $\mathrm{p}[\mathrm{mm}]$ & $\mathrm{q}[\mathrm{mm}]$ & $\mathrm{r}[\mathrm{mm}]$ & $1 \mathrm{l}[\mathrm{mm}]$ \\
\cline { 2 - 5 } & 957.979 & 268.2143 & 204.8341 & 738.0792 \\
\hline
\end{tabular}

\begin{tabular}{|c|c|c|c|c|c|}
\hline \multicolumn{4}{|c|}{ The reference value (CMM) $[\mathrm{mm}]$} & \multirow{2}{*}{\begin{tabular}{|c} 
LT[mm] \\
li
\end{tabular}} & \multirow{2}{*}{$\begin{array}{c}\text { Deviation }[\mathrm{mm}] \\
\operatorname{err}_{\mathbf{i}}\end{array}$} \\
\hline $\mathbf{x}$ & $\mathbf{y}$ & $\mathbf{z}$ & $\mathrm{Li}$ & & \\
\hline 350 & 489 & 482 & -34.3709 & -34.3707 & 0.0002 \\
\hline 390 & 506 & 498 & -56.1056 & -56.1055 & $\mathbf{0}$ \\
\hline 382 & 462 & 488 & -67.6411 & -67.6408 & 0.0003 \\
\hline 364 & 498 & 507 & -33.1563 & -33.1566 & -0.0003 \\
\hline 366 & 508 & 517 & -27.1759 & -27.1767 & -0.0007 \\
\hline
\end{tabular}

Table2. Experiment result

\section{4. 結果}

表 1 で示したシステムパラメータから,図 3 の 20 点の測定 点において得られた長さ測定の偏差の一部を表 2 に示す.

最大偏差 errmax は $0.7 \mu \mathrm{m}$ であり 20 点の長さ測定全体の標準 偏差は $0.5 \mu \mathrm{m}$ となった.つまりレーザ追尾式干涉計装置は $0.5 \mu \mathrm{m}$ 程度の測定精度と推測されるため,汎用の CMM や産業 用ロボットに対しては十分適用可能である.

今後は本装置の評価範囲を拡大し測定精度の検証を行う必 要がある.

\section{参考文献}

[1]H.Jiang et al :High-performance laser tracker using an articulating mirror for the calibration of coordinate measuring machine, Opt. Eng ,Vol41(3),(2002)p632-637 [2]矢野智昭 : 使いやすい球面ステッピングモータ,Aist Tody (2002)p16 